\title{
Capital Cities
}

\section{F. Homburg}

To cite this article: F. Homburg (1920) Capital Cities, Journal of Geography, 19:1, 8-15, DOI: 10.1080/00221342008984472

To link to this article: http://dx.doi.org/10.1080/00221342008984472

\section{Published online: 13 Feb 2008.}

Submit your article to this journal

Ull Article views: 11

Q View related articles $\asymp$ 
vergences become, the more certainly will the fortunes of Vienna again undergo vicissitudes that will recall the former, not wholly obliterated condition as a border town." The fear has now been realized. Vienna is not only capital of a greatly diminished state; she is very eccentrically placed in regard to it. What effect these changes will have on one of the world's great cities remains to be seen. Austria at least has now the advantage of embracing a homogeneous population; the non-German element is insignificant. ${ }^{5}$

5 J. Partsch: Central Europe, 1903, p. 212. On Vienna see also Vienna as a Type Gity, F. P. Gulliver, Journ. of School Geogr., Vol. 4, 1900, pp. 175-179, and Vienna, Charles MeMurry, Journ. of Geogr., Jume, 1914.

\section{CAPITAL CITIES}

By F. HOMBURG

Woodward High School, Cincinnati

Cities that are seats of government constitute a peculiar class. In them the head of the state or the chief executive resides, and hence in a monarchy the capital city is the residence of the court. In a republic it is the meeting place of the legislature and hence becomes the goal of office seekers and the Mecca of lobbyists. Here the highest law courts hold their sessions, and here are stationed the heads of the various government departments and a host of officials and employees. Here are the headquarters of national defense, of army and navy. In the train of these institutions come others. The various religious denominations find it for their interest to be well represented at the capital, and church dignitaries make their residence here. Universities and schools, libraries and museums make the capital a seat of learning, and it becomes a desirable dwelling place.

The capital city, drawing in to itself these various intellectual and material advantages, thus becomes a center from which radiates a cultural and nationalizing influence equalled by no other. This is the distinctive function of the capital city. Let us now inquire into the geographic causes that create and maintain it. 
ACCEssibiLITy

Accessibility is the first requisite of the capital city. The old saying "All roads lead to Rome" reflects the central location and accessibility of the capital of the ancient world. It is expected that a capital will be centrally situated - central, that is, with chief reference to distribution of population. We may take examples from our own state capitals. Where there is a general uniformity of surface with a generally even distribution of population and more or less equal transportation facilities, the capital tends to the center of the state, as Columbus, Ohio. In Nebraska or Kansas, where climatic conditions hold the mass of population in the east of the state, the capital is out of the geometrical center. ${ }^{1}$

\section{Changes of Location Through Growth of the Country}

Here, however, we are confronted with an element of change. The center of population may shift position very much, especially in recently developed lands or where there is a general change of occupation as from agriculture to industry. The center of area, too, may be unstable; a country may acquire or lose territory.

During the wars of the Christian States in Spain against the infidels Valladolid, the capital of Castile, most powerful of these states, eventually became capital of the whole country. After the complete overthrow of the Moors and the acquisition of Granada, Valladolid was situated too far north. Since 1560, Madrid, near the geographic center of Spain, has been the capital. The kingdom of Sardinia, or Piedmont, in the middle of the last century was the most vigorous of the Italian states, so that at the time of the partial union of Italy its capital, Turin, naturally became the capital of the Italy of that day. When more territory was acquired the position of Turin proved too eccentric, and in 1864 the seat of government was transferred to Florence. It is interesting to look at the maps of the sixties and note these changes. Finally, when in 1870 the whole peninsula and all of the islands (except Corsica) were united under one government, Rome, because of its central position as well as because of tradition, was restored to its ancient place as capital.

1 For a discussion of the location of political centers in the United States see W. S. Tower: The Geography of Ameriean Cities, Bull. Amer. Geogr. Soe., Vol. 37, 1905, p.p. 577-588. 
Temporary ShrFts in War Time

The capital city of an important country is typically cosmopolitan. A great capital will not only have easy communication with the various parts of its own country; it will have good communications with other countries. The situation of Copenhagen between the Baltic and North Seas is a case in point. This feature, so advantageous in times of peace, may operate otherwise in time of war. And here we may note the case of Belgrade so eccentrically placed on the northern frontier of Serbia.

From remote periods it has always been the object of military campaigns to capture the enemy's capital; the heart of organization. If the situation grows serious the capital of the threatened country may be changed. Thus in 1865, when the Federal forces were closing in on Richmond, the Confederate authorities ordered the transfer of the government archives to Danville, on the North Carolina border, intending to make that town the Confederate capital; but the order came too late. In 1870, when Paris was invested, the seat of government was transferred to Tours; and again in 1914, when another siege of Paris seemed imminent, Bordeaux was made the capital. In the late war, also, when Petrograd was threatened, Moscow came into its own again, as the Russian capital; and, when Bucharest was taken, Jassy, close to the Russian border, became the Rumanian capital. Perhaps the most anomalous case was that of Belgium with the seat of government transferred to Havre. But, though archives and officials may be removed, much that goes to the making of a capital city is immorable, and the moral effect of its capture is proof of the influence of such a city in the country's life.

\section{Fortification}

Hence arises the question of fortification of the capital city. Many ancient capitals, as of course other ancient cities, enjoyed the advantages of natural defense in their site: ancient Paris, for example, on an island of the Seine; ancient Rome on her seven hills. Modern cities are usually strongly fortified, especially if their situation be exposed. Paris is an enormous military camp, and advantage has been taken of the unique natural defenses in the Paris Basin for the protection of the city."

2 D. W. Johnson: Topography and Strategy of the War, New York, 1917, pp. 2-10. 
Polimical Importance as a Factor in Growth

A capital city grows in virtue of its political importance, but other factors enter in whose relative importance it is difficult to estimate. On the site of Washington, at the "fall line" and head of navigation of the Potomac, a town would undoubtedly have sprung up but, had it not been a capital, we may be sure it would not have had the population, beauty, or influence that Washington has. The site of Paris is inevitably that of a great town, and Paris is naturally placed as the capital of modern France; but it is interesting to speculate on the consequences had Hugh Capet at the end of the tenth century selected as his capital not Paris, but the more centrally situated Orleans. The phenomenal growth of Berlin after it became capital of the German Empire, the expansion of Buda-Pest after 1866, the increase in size and beauty of modern Rome since it became head of united Italy are due to their political status.

Usually the features of site and situation ${ }^{3}$ that make for the selection of a political center also make for other factors that promote growth, and the greatest capital cities show this. A more detailed discussion of some of these cities will best illustrate this and the other features that we have mentioned.

Rome, the Eternal City

No city appeals so strongly to the imagination as that capital of all capitals, the Eternal City, Rome. Rome owes much of its greatness to geographical causes. As has already been remarked, the volcanic hills afforded positions of natural defense. Below stretched the broad, fertile plain of Latium. The site marked a crossing place on the Tiber, which was then a much more navigable river than it now is. As regards situation Rome was center of the civilized Old World. No such cosmopolitan capital has ever existed. Administration and commerce as a matter of course drew many people thither; but in addition there were many attractions for others, which increased with the city's growth as a center of luxury. The emperors, having continued to support the mob by free distribution of grain, had also to assume the burden of its entertainment. The cry of "bread and games" attracted adventurers and fortune seekers from all parts of the Empire. The

3 Site is concerned with local conditions; situation with relations further afield. 
dominance of Rome in the ancient world is reflected in the vast significance that attached to Roman citizenship and in the extent to which the imperial city figured as a model for provincial towns. Her fine streets, her forum, theatres, and baths were imitated everywhere; so too her Circus Maximus with its races and her Coliseum with its games.

Various forces made for the disruption of the Empire with its long stretch from west to east. The division of government with creation of an eastern capital, Constantinople, was the beginning of a permanent division, in which as the old western capital declined the sun of the new eastern capital rose.

Constantinople: at the Crossways of trie Old World

When Rome was ravaged by the barbarian hordes of the north the role of conservator of the ancient civilization fell upon the city of the Bosporus. Constantinople is remarkably placed both as regards site and situation. The Golden Horn affords an extensive, deep-water harbor commanding the crossing point of two of the world's great highways, the north-south seaway from the Black Sea to the Mediterranean and the land route from Europe to Asia whose latest phase has become famous as the "Berlin to Bagdad" route. For centuries Constantinople figured as the capital city of the world, a London and a Paris in one, the center of commerce and of culture. Its commercial importance, due to its exceptional position, was not diminished by the rise of the Saracens. After their early fanaticism had been spent Constantinople continued to be the point where products of the East were exchanged for those of the West, and as an emporium it flourished down to the time of the Crusades when Venice took over much of the Eastern trade. After its conquest by the Turks in 1453 the city on the Bosporus became the eapital of another Empire and, despite centuries of Turkish misrule, has remained one of the great cities of the world. What will be its fate after the conclusion of peace is still to be seen, but nothing can rob the eity of its immense natural advantages.

\section{Paris: a Capital City par excellence}

Of modern capitals none show so markedly the concentration of political power and cultural influence as Paris. So pronounced 
is this concentration that it has tended to thwart the growth of other eities in France. This effect is seen in the retarded development of towns within 60 to 90 mile radius, the maritime ports excepted. Troyes, Rheims, Amiens and other towns which formerly figured as capitals are in a condition of relative stagnation. Against this concentration there is now on foot a movement towards decentralization under which the regional divisions and their regional capitals will be more free to follow the natural lines of growth. ${ }^{4}$

Paris well illustrates the principle that a capital city should be accessible. The Paris Basin is a place of convergence for natural roads not only from the several regions of France but from farther afield. Here meet roads from the Mediterranean, from the highland zone of central Europe, from the north German plain and thus through European Russia from Asia, from Britain, and from Brittany and the West. It is this position as a meeting place for peoples and ideas that has given Paris its surpassing importance as a center of cultural influence.

Berlin as a capital is in sharp contrast with Paris. The north German plain, naturally a poor and unattractive region, is rather a passageway than a meeting place, and even so the position of Berlin is eccentric. Especially now, with the re-establishment of Poland and the pushing westward of Germany's eastern boundary, is the eccentric position of Berlin emphasized and its character as a strategic and military center apparent. Berlin lacks the cultural heritage of Paris or of some of the old German cities such as Leipzig. It has failed to fill the function of a true capital-the centralizing of national life.

\section{Petrograd and Moscow}

If Berlin is an artificial creation as a capital still more so is Petrograd. Petrograd, however, was founded with a different aim in mind. Peter the Great well knew what the influence of a capital means. He wished to introduce the civilization of western Europe into his vast domain and he replaced Moseow, the ancient capital, with the foundation of St. Petersburg in the marshy tract at the head of the Gulf of Finland. The site was unattractive, but there

4 De Martonne: The Real France, Journ. of Geography, March, 1919. 
were advantages of situation. So, in spite of the marshy ground, the inundations, the barren surroundings, the damp, unhealthy climate, and the long ice blockade of winter the new capital grew and it grew, moreover, as a west European city. Petrograd is situated on the easternmost extension of the Baltic Sea, at the mouth of the Neva, the short, deep outlet of Russia's great lakes. It is not far from the Russian watershed, the Valdai Hills, from which the most important Russian streams radiate and whence also canal communication is easy. Thus Petrograd became the first commercial port of Russia.

Business and government brought together a very mixed population, not only from all parts of European and Asiatic Russiawhich is a realm of many distinct peoples and languages-but from other countries as well. Petrograd, with a population more cosmopolitan than characteristically Russian, has exerted a cultural influence, as was intended by its founder, but hardly a nationalizing one. This is strongly felt by the Russian people themselves, and their feeling finds expression in the popular saying that while Petrograd was the head of Russia, the ancient capital, Moscow, was its heart. Moscow is the greatest commercial center of the interior. It is well placed as regards waterways, and, as anciently the roads, modernly the railways converge towards the city. With its memories dear to every patriotic Russian, with its ancient heritages and institutions, the nationalizing influence of Moscow far exceeds that of Petrograd.

Some Capitals of the New World

Of the capitals of the New World republics one of the most interesting is that of Brazil. As capital of the largest South American state the situation of Rio de Janeiro on the eastern coast is very eccentric so far as area is concerned, but the coastal region has been longest settled and is most populous. Roads and railroads, however, are beginning to open up the vast interior, and Brazil's interests in her remote boundary regions must be other than political. With such development the eccentric position of Rio will become more apparent. Rio, however, presents many advantages as a capital. The site is one of almost unrivaled beauty. The foundation is comparatively old, and the city can 
show a full share of fine buildings, beautiful churches, and interesting museums, while among educational features is the worldrenowned botanical garden. The magnificent harbor and its central location on the Brazilian seaboard have made Rio a great commercial center, and, since yellow fever has been eliminated, the city has had unhampered opportunities as a port.

The positions of Montevideo, the Uruguayan eapital, and Buenos Aires, the Argentine capital, are similarly eccentric, and the same is true of our own capital. In all these countries there have been proposals and even efforts to change the location of the capital. In our own country Chicago has had hopes of superseding Washington, and some persons see in St. Louis the future capital because of its nearness to the center of population and its more central areal position. In contrast with European countries expansion in these countries of the New World has been very recent, and it may well be that readjustments must be made.

\section{The Capital of the Australian Commonwealth}

When on January 1, 1901, the six independent colonies of the Island Continent, with discordant interests and mutual jealousies, were united in one federation the question of a federal capital came up. To avoid irritation none of the state capitals was selected, but choice was finally made of a site, Canberra, in the southeastern corner of New South Wales. The position, of course, is eccentric to the area of the continent, but, as in the case of the American colonies, settlement began on the seaboard. The east, more especially the southeast, is the densely populated part of the continent; and in the case of Australia one cannot look for extensive development in the arid lands of the interior. 